\title{
DE DE GRUYTER

\section{EFFECTS OF HAIL SUPPRESSION OPERATIONAL PROGRAMS ON HAIL FREQUENCY AND ENVIRONMENT IN MOLDOVA}

\author{
V. Cazac ${ }^{1}$, M. Daradur ${ }^{2}$, Tamara Leah ${ }^{3}$, R. P. Pandey ${ }^{4}$
}

Keywords: Hail Frequency, Hail Suppression, Republic of Moldova

\begin{abstract}
Hailstorms pose a significant threat to all development sectors of the Republic of Moldova. Despite the availability of the intensive hail suppression operational programs the issues of their efficiency are very relevant for many years. In spite of expectations and previous claims the research findings show that the hail suppression activity in Moldova leads to increase of hail incidence rate (statistically tested at the 0.05 confidence level). Active influence on the hail formation processes has also environmental implications leading to the increased pollution of the environment by the active anti-hail components in the protected areas. Given the controversial effects and missing reliable estimates of the economic benefits, as well as environmental implications, additional investments for developing of the anti hail operational programs is not recommended.
\end{abstract}

\section{Introduction}

The Republic of Moldova which is located in South-Eastern part of Europe is highly vulnerable to the frequent hail and related weather and climate extremes (Daradur et al., 2009; Leah, 2013; Sidorenco et al., 2013; Bugaev, 2016). Despite local-scale characteristics, severe hail and associated high impact weather phenomena, such as a torrential rainfall, gusty wind, etc. cause considerable damage mainly to environment, as well as agriculture, buildings, transport and infrastructure, yielding $50 \%$ of the total damage that is comparable with drought impact. Herewith, severe hail is responsible for $13 \%$ of the total damage from high impact weather and climate events exclusively, reaching in the single years (2012) MDL $215 \mathrm{mln}$. (US \$ $14.5 \mathrm{mln}$.). Due to small spatial extent, the hail hazard is a great challenge for prediction and estimates its occurrence, especially in the areas

\footnotetext{
${ }^{1}$ State Hydrometeorological Service, valeriucazac@hotmail.com

${ }^{2}$ Research and Project Centre, m.i.daradur@gmail.com

3 "Nicolae Dimo" Institute of Soil Science, Agrochemistry and Soil Protection tamaraleah09@gmail.com

${ }^{4}$ National Institute of Hydrology Roorkee India, rppanndey@gmail.com
} 
with a less dense of the weather observation network (Kunz and et al., 2009). The main conditions associated with hail formation processes are a combination of the surface air temperatures and moisture contents that particularly lead to the instability of the atmosphere stratification and developing convective processes (Fig.1).
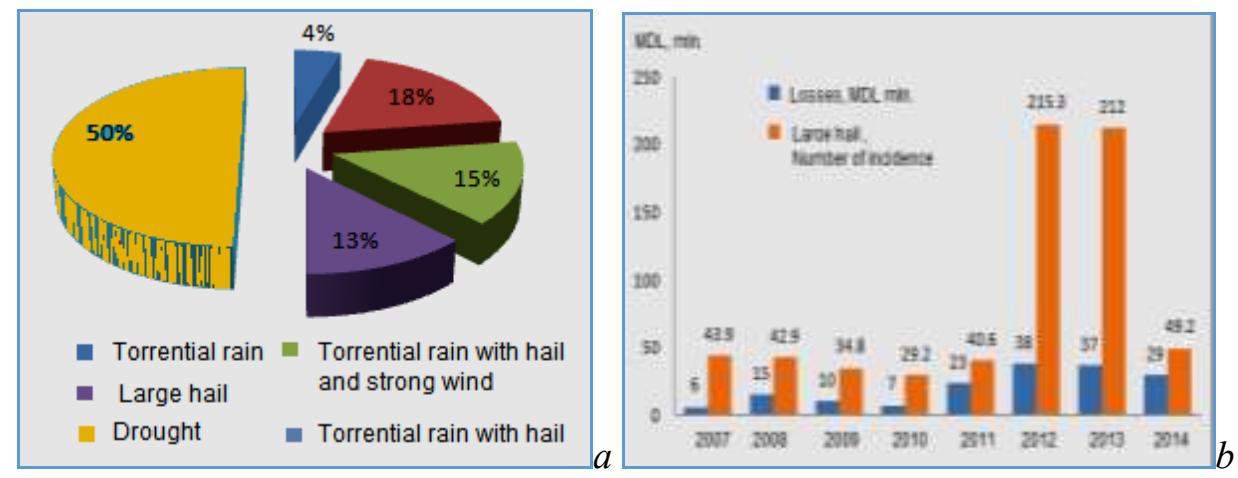

Fig. 1 Attribution (\%) of the economic losses to hail (a) and other high impact climate events (b) in the Republic of Moldova

Source: National Burro of Statistics; Civil Protection and Emergency Situations Service.

The terrain influence, which often neglected, also may promote to hail formation by modifying the heat transport and triggering forced convection, resulting in serious destructions in natural environment (Cotton et al., 2007; Suwała and Bednorz, 2013).

The damage, mainly in agriculture, caused by severe hail prompted the need to find ways to protect farmlands. In this regard, in the mid 1960-ies an operational program on hail suppression based on glaciogenic cloud seeding approach was initiated by the former Ministry of Agriculture of Moldavian SSR. Currently Moldova has an operational program under Special Service for Active Influence on Hydro-meteorological Processes (SSAIHP) which use the rocket technology to transport a nucleating reagent (silver iodide - AgI) into hail-producing clouds. The basic elements of the hail protection technology are a specialized anti-hail rocket system "Alazan-6" for cloud seeding with hail-watch radar signal returns from cloudy cells and a specialized automatic control system ACS-MRL. The system provides collection and processing of the radar-tracking data about clouds with hail-watch radar return signal and gives information about the type of falling precipitation (Sidorenco et al., 2013). The system allows control of the cloudy atmosphere for checking the probability of hail formation over the whole territory of Moldova as well as over a border-part territory of Romania and Ukraine (up to $100 \mathrm{~km}$ from the border) in a non-stop mode. 
Despite the availability of the intensive hail suppression operational programs the issues of their efficiency are very relevant for many years. According to Sidorenco et al. (2013) and more recent sources (SSAIHP, 2015), in the Republic of Moldova the applied hail suppression technology provides a high operational efficiency; vary from $84 \%$ to $92 \%$. However, despite the high efficiency has been claimed, caution is recommended (World Bank, 2007; Cotton et al., 2007; Daradur et al., 2009; Court of Account..., 2012) since most of hail suppression experiments have been inconclusive and convincing cost-benefit analysis has not been possible.

The Expert Team on Weather Modification Research of the WMO is also very cautious regarding the estimated effects of anti-hail operational projects and repeatedly reminds that up to date the seeding approach to prevent hail formation remains controversial (WMO, 2010). In the particular case of Moldova, it is significantly that these estimates are not consistent with the damages caused by hail reported by the Civil Protection and Emergency Situations Service (World Bank, 2007).

This investigation has been undertaken in an effort to assess an effect of the regional operational programs on the hail rate occurrence in the Republic of Moldova. Based on the Moldavian long-term (1967-2015) anti-hail operational programs and the observed hail data from State Hydrometeorological Service in Moldova, an attempted has been to reveal the causes of regional hail rate reducing using a statistical approach. In the contrary to expectations the research findings show that the efficiency assessments of the hail suppression programs in Moldova may be not so convincing.

\section{Data and methods}

The information on the long-term operational programs under SSAIHP in the Republic of Moldova has been subjected to the statistical analysis to estimate effects of an active influence on the regional hail occurrences. Given the considerable change in the regional environments related to the hail generation in a changing climate (Nedealcov, 2013; Sutton et al, 2013; Taranu, 2014; Daradur et al., 2015), we eliminated climate trends from the actual hail days variability. Student's $\mathrm{t}$ test has been applied for long term linear trend detection in the hail day dynamics. Then, detrended mean annual hail data over the Republic of Moldova have been correlated with the area under anti-hail protection in the implemented nonlinear regression.

The area (ha) under anti-hail protection have been used as a explanatory proxy factor, indicating the scale of the anti-hail activities and the intensity of the influence on convective processes, since it closely correlates with the number of rockets lunching points with $r=0.94$. The information on this variable is the most comprehensive and it is long enough (1967-2015) to reveal the effects of hail 
suppression programs on hail occurrences using a statistical approach. The hail day's data recorded at 8 stations (evenly distributed over the protected areas and having the most continuous hail day's time series from 1949 to 2015) was used in the analysis. The nonlinear model of the relationship between the mentioned factors was calculated using the ordinary least squares regression (Wilks, 1995; Smith, 2001). Statistical significant of the effects of the long-term anti-hail operational programs on hail frequency was tested at the 0.05 confidence level using a t- test (Fig.2).

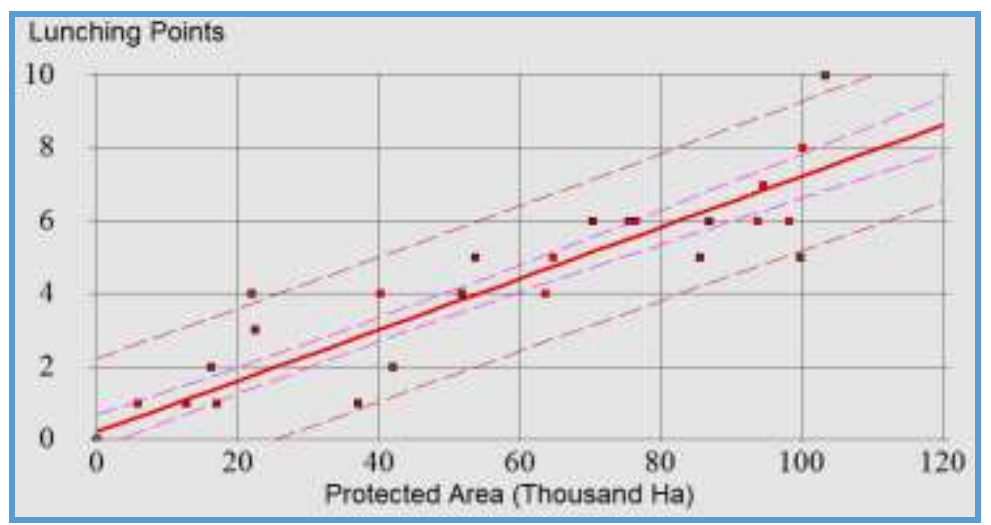

Fig. 2. Correlation $(r=0.94)$ of the number of anti-hail rockets lunching points and area under hail protection

The environmental implications of the anti-hail programs based on the limited available data from 1983 to 1991 on the concentration of the active reagents in the water ponds of the Republic of Moldova (Potapov and Plaude, 1996). There after, due to a social and economic transformation and limited resources in the post soviet period, the monitoring on these variables was canceled. The estimates were based on the comparison of the concentration of active artificial ice-forming substances - AgI in the protected and the control (not covered by anti-hail programs) areas. The implications of the revealed distinctions have been not considered on the study and their discussion is inappropriate at this point.

\section{Results and discussion}

2.1. Effect on the hail frequency. Hail suppression through cloud seeding technologies is controversial for several reasons (Mesinger and Mesinger, 1992, WMO, 2010). First of all, to date the physical principles underlying the seeding approach is a matter of some argument. Another critical reason are widespread and costly operational activities in place concurrent with an absence of a relevant performance indicators used to arrive at claims of effect established in the sector 
policy (World Bank, 2007; Daradur et al., 2010; WMO, 2010; Court of Account..., 2012).

Tab. 1. Protected areas and the number of lunching point for anti-hail rockets (Administrative districts of the Republic of Moldova)

\begin{tabular}{|c|c|c|c|c|c|}
\hline № & District & $\begin{array}{l}\text { Total area, } \\
\text { thousand ha }\end{array}$ & $\begin{array}{l}\text { Protected area, } \\
\text { thousand ha }\end{array}$ & $\begin{array}{l}\text { Share of protected } \\
\text { area, thousand ha }\end{array}$ & $\begin{array}{l}\text { Lunching } \\
\text { point }\end{array}$ \\
\hline 1 & Anenii Noi & 88.8 & 0 & 0 & 0 \\
\hline 2 & Basarabeasca & 29.5 & 0 & 0 & 0 \\
\hline 3 & Briceni & 81.4 & 51.7 & 63.5 & 4 \\
\hline 4 & Cahul & 154.5 & 16.2 & 10.5 & 2 \\
\hline 5 & Cantemir & 86.8 & 5.7 & 6.6 & 1 \\
\hline 6 & Calarashi & 75.4 & 75.4 & 100 & 6 \\
\hline 7 & Causheni & 131.1 & 0 & 0 & 0 \\
\hline 8 & Cimishlia & 92.4 & 0 & 0 & 0 \\
\hline 9 & Criuleni & 68.8 & 0 & 0 & 0 \\
\hline 10 & Dondusheni & 64.4 & 63.6 & 98.8 & 4 \\
\hline 11 & Drochia & 100.0 & 99.9 & 100 & 5 \\
\hline 12 & Dubasari & 30.9 & 0 & 0 & 0 \\
\hline 13 & Edinetz & 93.3 & 85.6 & 91.8 & 5 \\
\hline 14 & Faleshti & 107.3 & 93.7 & 87.4 & 6 \\
\hline 15 & Floreshti & 110.8 & 98.2 & 88.6 & 6 \\
\hline 16 & Glodeni & 75.4 & 64.8 & 85.9 & 5 \\
\hline 17 & Hinceshti & 147.2 & 22.4 & 15.2 & 3 \\
\hline 18 & Ialoveni & 78.3 & 0 & 0 & 0 \\
\hline 19 & Leova & 76.5 & 0 & 0 & 0 \\
\hline 20 & Nisporeni & 62.9 & 53.6 & 85.2 & 5 \\
\hline 21 & Ocnitza & 59.7 & 40.2 & 67.3 & 4 \\
\hline 22 & Orhei & 122.8 & 21.9 & 17.8 & 4 \\
\hline 23 & Rezina & 62.2 & 0 & 0 & 0 \\
\hline 24 & Rishcani & 93.6 & 86.8 & 92.7 & 6 \\
\hline 25 & Singerei & 103.4 & 103.4 & 100 & 10 \\
\hline 26 & Soroca & 104.3 & 70.4 & 67.5 & 6 \\
\hline 27 & Strasheni & 72.9 & 42 & 57.6 & 2 \\
\hline 28 & Sholdaneshti & 59.8 & 12.6 & 21.1 & 1 \\
\hline 29 & Shtefan Voda & 99.8 & 0 & 0 & 0 \\
\hline 30 & Taraclia & 67.4 & 17 & 25.2 & 1 \\
\hline 31 & Teleneshti & 84,9 & 76,5 & 90,1 & 6 \\
\hline 32 & Ungheni & 108,3 & 94,5 & 87,3 & 7 \\
\hline 33 & Chishinau & 57,2 & 0 & 0,0 & 0 \\
\hline 34 & Baltzi & 7,8 & 3,7 & 47,4 & 1 \\
\hline 35 & Bender & 3,9 & 0 & 0,0 & 0 \\
\hline 36 & Gagauzia & 184,8 & 100,1 & 54,2 & 8 \\
\hline \multicolumn{2}{|c|}{ Total } & 3048,4 & 1399,9 & 45,9 & 108 \\
\hline
\end{tabular}

A few randomized trials have been conducted for hail suppression using such measures as hail mass, kinetic energy, hailstone number and area of hail fall (see, for example, Farazoulis, 2015) which have not been conclusive (WMO, 2010). Most attempts at evaluation have involved non-randomized operational programs 
using historical trends in crop hail damage, sometimes with target and upwind control areas. Despite large reductions having been claimed by many studies the weight of scientific evidence to date is inconclusive and operational programs should strengthen the physical and evaluation components of their efforts (WMO, 2010).

According to the SSAIHP in 2015 the area being under the hail protection was about 1.5 million hectares, i.e., $50 \%$ of the territory of the country. In the single years up to $75-80 \%(2.5 \mathrm{mln}$. ha) of the total area of Moldova was under hail protection programs (Tab.1).

This multiannual information on protected areas has subjected to the statistical analysis and correlated with detrended hail data to eliminate climate change effects. The contribution of regional climate change, expressed by the trend component, ensures about $25 \%$ of hail day's variability (Fig. 3 ).

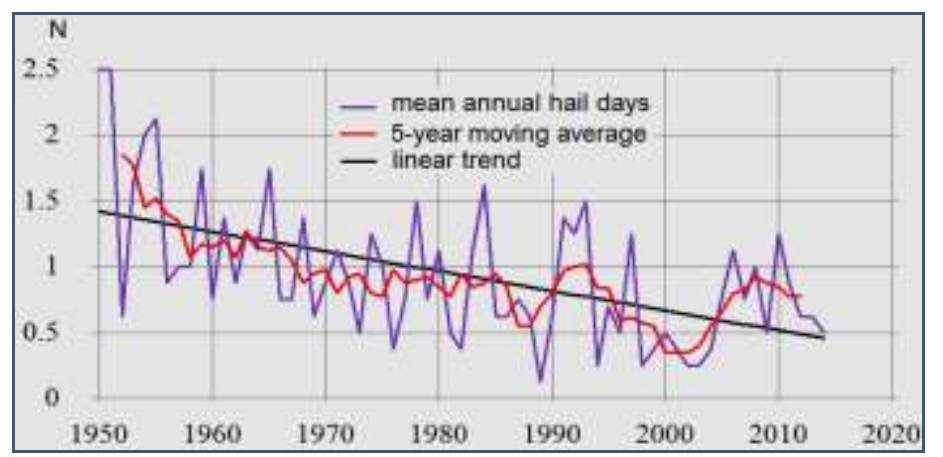

Fig. 3. Long-term dynamics of the average number of days with hail incidence

The nonlinear model of the relationship between the detrended hail data with the area under hail protection, calculated using the ordinary least squares regression, is presented in the Fig. 4. The figure illustrates that in the contrary to expectations and previous claims that hail suppression in Moldova decreases hail frequency, the research shows that intense anti-hail activity lead to increase of hail incidence rate.

Correlation coefficient (r) constituted 0.49 that means about $14 \%$ of variability of detrended hail data are attributed to hail suppression operational programs. Statistical significant of the effects of the long-term anti-hail operational programs on hail frequency was tested at the 0.05 confidence level.

A more illustrative case of the effects of climate change and hail suppression operational programs on hail variability is shown on the Fig. 5. The contribution of regional climate change, expressed by trend component, ensures about $25 \%$ of hail 
days variability (blue line), where as the impact of anti-hail programs is limited by $14 \%$ of detrended data (highlighted by yellow color). Nevertheless the
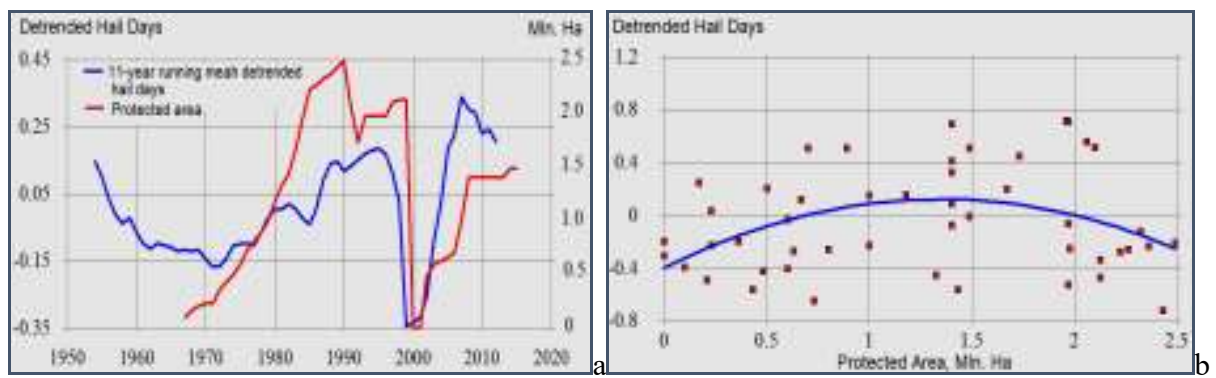

Fig. 4. Long-term dynamics of detrended days* (a) with hail incidence and its correlation with area (b) under hail suppression

*Note: Detrended hail days was smoothed to eliminated high frequency variation

contribution of the hail suppression programs has an observable effect on the hail variability leading to increasing the hail occurrences rate during the period of operationally using the extensively practiced cloud seeding technologies to reduce hail damage.

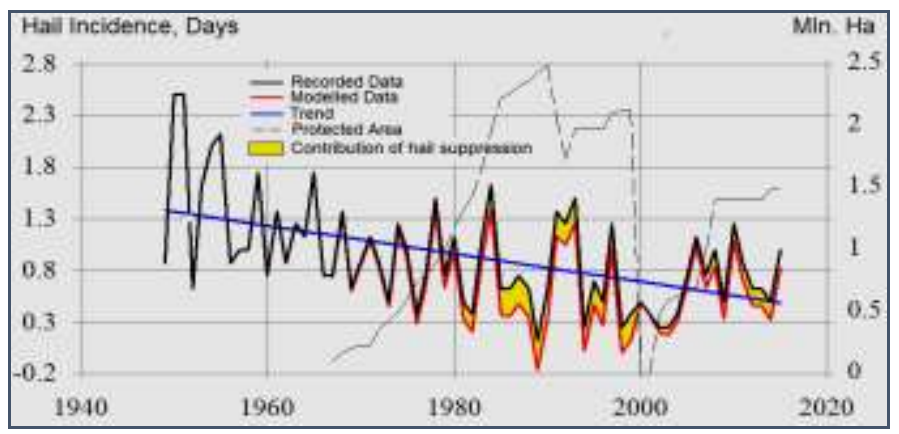

Fig. 5. Time series of average hail event number (1949 - 2015) over the Republic of Moldova and contribution of hail suppression activities (highlighted by yellow color).

Note: Red line shows the modeled data without anti-hail programs impact; dotted line is protected area

Hence, in the contrary to expectations, the anti-hail operational programs promote to an increase of the hail frequency. The research indicates that the claims of SSAIHP on the effectiveness and cost benefit analysis are not convincing. Since the Republic of Moldova there is no reliable estimate of the economic benefits of the operational hail suppression programs it is recommended to refrain from additional investment in expanding the anti-hail program and introduce more effective cost-benefit approach (Word Bank, 2007; Court of Account..., 2012). 
2.2. Environmental implications. As noted above, the hail suppression activity in Moldova based on the rocket technology of transportation and dissemination of a nucleating reagent (AgI) into hail-producing clouds. The anti hail program started with the cloud systems to be processed by rockets with containing $0.8-2.0 \%$ of the active reagents and to increase those components up to $8 \%$ since 2003 (Sidorenco et al., 2013).

An analysis of the available data, limited from 1983 to 1991 on the concentration of the active reagents in the water ponds of the Republic of Moldova indicates on the similar dynamics of the accumulation of silver compounds in the protected and control areas (Fig.6). That is not surprising since it is well known that the reagent particle with decaying cloud elements can be carried on quite long distances, up to $100 \mathrm{~km}$ (Potapov and Plaude, 1996).

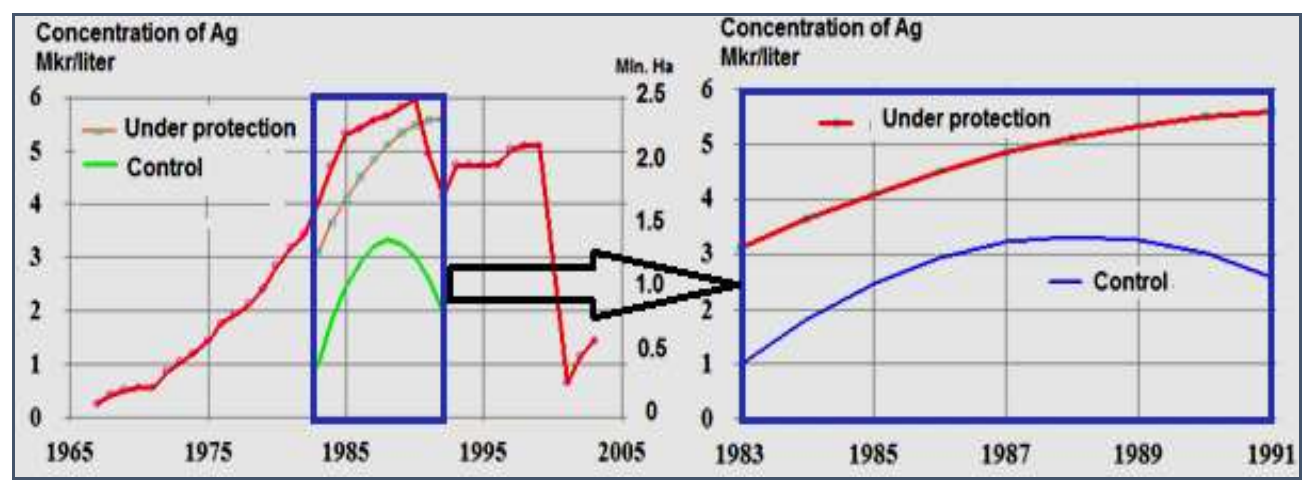

Fig. 6. The conjugate dynamics of the protected area (mln. ha) and concentration of antihail active reagents $\left(\mathrm{mg}^{-1}\right)$ in the water pond of the Republic of Moldova

At the same time, in the protected areas the average levels of contamination by a silver components are twice, even more $\left(3.0-6.0 \mathrm{mg}^{-1}\right)$ while in the control areas (not covered by programs), these estimates do not exceed the values of 1.0-3.0 mg1 .

\section{Conclusion and recommendations}

Despite the availability of long-term hail suppression operational program the Republic of Moldova is highly vulnerable to the frequent hail. According the estimates, severe hail and associated high impact weather phenomena, such as a torrential rainfall, gusty wind etc. cause considerable damage to all development sectors, yielding $50 \%$ of the total damage from weather and climate extreme events and having a tendency to increase. 
The research findings indicate that the previous claims of the SSAIHP are not convincing and considerable reducing the hail incidence in Moldova is conditioned by the climate change effects, leading to alteration of a natural environment of hail formation, first of all surface temperatures. According to the estimates regional climate change ensures about $25 \%$ (based on the linear trend assessments) of the long-term variability of hail days.

Given the climate change effects on hail days variability, in the contrary to expectations the investigation shows that the hail suppression activity in the Republic of Moldova leads to increase of hail incidence rate that is statistically tested at the 0.05 confidence level. Active influence on the convective processes has also environmental implications related to the increasing pollution of the environment by the active anti-hail components (AgI) in the protected areas.

Considering the controversial effects and missing reliable estimates of the economic benefits, as well as the environmental implications anti-hail activity, additional investments in the hail suppression operational programs in the Republic of Moldova is not recommended.

\section{References}

Bugaev, T. (2016). Extreme meteorological phenomena in the Republic of Moldova. Retrieved from: http://dx.doi.org/10.1016/j.atmosres.2012.04.002

Cotton, W., Pielke, Sr., Roger A. (2007). Human Impacts on Weather and Climate. Cambridge. UK, Cambridge University Press, 2007. 978-0-521-60056-9

Daradur, M., Fedotova L., Nedialcov, M. (2010). Natural-based approach to regional climate monitoring and risk assessment. World Universities Congress, October 19 24, Canakkale, Turkey.

Daradur, M., Cazac, V., Fedotova L. (2009). Hail incidence and some ecological consequences of hail suppression in Moldova. Moldavian Agricultural University. Chisinau (in Russian)

Daradur, M., Chirica, L., Cazac, V., Pandey, R. (2015). New Drought Products: Transforming Drought Information to Facilitate Decision Making. Chisinau, Research and Project Centre "Eco Logistica".

Farazoulis, G. (2015).The modern reality of a Hail Suppression Program's application. WMA. Retrieved from: http://www.contingencias.mendoza.gov.ar/web1/pdf/Farazoulis.pdf

Kunz, M., J. Sander, and C. Kottmeiera. (2009). Recent trends of thunderstorm and hailstorm frequency and their relation to atmospheric characteristics in southwest Germany. International Journal of Climatology, 29, 2283-229. doi:10.1002/joc.1865.

Leah., T. (2013). Soil degradation and conservative technologies: two incompatible realities for Republic of Moldova. ProEnvironment, Vol. 6, 14.

Mesinger, F. and Mesinger, N. (1992). Has hail suppression in Eastern Yugoslavia to a reduction in the frequency of hail ? Journal of applied meteorology, 31, 104-111 
Nedealcov, M. (2013). Exposure of the Republic of Moldova to some climate risks. Present Environment and Sustainable Development, v.7 (2).

Potapov, Ye. I. and Plaude, N. O. (1996). Stydy on environmental pollution in a hail protected area. Journal of Applied Meteorology, 35 / 9, p. 1542.

Sidorenko, A., Garaba, I., Potapov, E., Zasavitsky E. (2013). Advanced technology for active hail suppression in the Republic of Moldova. Resources of Danubian region: the possibility of cooperation and utilization, Belgrade, June 12-15, 2013.

Smith, K. (2001). Environmental Hazards: Assessing Risk and Reducing Disaster. Routledge, 3rd Edition, ISBN0-415-22463-2, pp. 398

Sutton, William R., Jitendra P. Srivastava, James E. Neumann, Ana Iglesias, and Brent B. Boehlert (2013). Reducing the Vulnerability of Moldova's Agricultural Systems to Climate Change: Impact Assessment and Adaptation Options. World BankStudy. Washington, DC: World Bank. doi:10.1596/978-1-4648-0045-0. License: CreativeCommons Attribution CC BY 3.0.

Suwala, K. and Bednorz, E. (2013). Climatology of hail in Central Europe. Quiestiones Geographicae, 32 (3).

Taranu, L. (2014). An assessment of climate change Impact on the Republic of Moldova's agriculture sector. A research study complementing the vulnerability and adaptation chapter of the third national communication of Moldova under the United Nations Framework Convention on Climate Change. Chisinau: Tipografia Centrală.

Wilks, D. (1995). Statistical methods in the atmospheric sciences: An Introduction. Int. Geophys. Ser., 59, 467 pp. Academic, San Diego, California

World Bank (2007). Rural productivity in Moldova: Managing natural vulnerability. Washington, DC: World Bank. Retrieved from: http://documents.worldbank.org/

*** Court of Account of the Republic of Moldova (2012). Decision Nr. 38 from 03.08.2012 on the Report of the audit assessment of the financial management system on the procurement of anti-hail rockets of the Special Service for weather modification. http://lex.justice.md/viewdoc.php?action=view\&view=doc\&id=344765\&lang=2

***Special Service for Active Influence on Hydro-meteorological Processes (2015). Retrieved from: http://www.antigrindina.md/indexr.html

***WMO (2010). Executive summary of the WMO statement on weather modification. WMO documents on weather modification. Updated in the meeting of the Expert Team on Weather Modification Research. Abu Dhabi, 22-24 March 2010. Retrieved from: https://www.wmo.int/pages/prog/arep/wwrp/new/ 